\title{
KULIT BUAH JERUK LIMAU (Citrus amblycarpa (Hassk.) Osche) SEBAGAI ANALGESIK
}

\author{
R. A. I. K. Maharani, N. K. Cahyaningsih, M. D. Abimanyu, dan K. W. Astuti* \\ Program Studi Farmasi, Fakultas Matematika dan Ilmu Pengetahan Alam, Universitas Udayana, \\ Bukit Jimbaran, Badung, Bali \\ Laboratorium Analisis Program Studi Farmasi, Fakultas Matematika dan Ilmu Pengetahuan \\ Alam, Universitas Udayana, Bukit Jimbaran, Badung, Bali \\ *Email: ketutwidyani@yahoo.com
}

\begin{abstract}
ABSTRAK
Nonsteroidal anti-inflammatory drugs (NSAID) menjadi salah satu pilihan terapi untuk menghilangkan rasa nyeri. Namun, penggunaan jangka panjang dapat memicu pendarahan gastrointestinal. Oleh karena itu, diperlukan analgesik alternatif yang memiliki efek terapi yang sama dan efek samping yang lebih rendah, salah satunya adalah Jeruk Limau (Citrus amblycarpa) yang dimanfaatkan sebagai obat kesemutan dan kram secara empiris. Penelitian ini dilakukan dengan tujuan untuk mengetahui aktivitas analgesik pada ekstrak etanol kulit buah C. amblycarpa. Metode yang digunakan dalam pengujian aktivitas analgesik adalah metode Hot Plate. Penelitian dilakukan dengan membagi 30 ekor mencit ke dalam 6 kelompok yakni kelompok yang diberikan CMC-Na $1 \%$ sebagai kontrol negatif, suspensi natrium diklofenak dosis $6,5 \mathrm{mg} / \mathrm{kgBB}$ sebagai kontrol positif, dan suspensi ekstrak etanol kulit buah $C$. amblycarpa dengan variasi dosis $100 \mathrm{mg} / \mathrm{kg} \mathrm{BB}, 300 \mathrm{mg} / \mathrm{kg} \mathrm{BB}$, dan $600 \mathrm{mg} / \mathrm{kg}$ BB. Hewan uji ditempatkan diatas Hot Plate dengan suhu $70^{\circ} \mathrm{C}$ pada 30 menit setelah pemberian suspensi uji dan diamati waktu respon mencit terhadap panas setiap 30 menit selama 3 jam dengan waktu cut off 15 detik. Berdasarkan hasil uji aktivitas analgesik ekstrak etanol kulit buah C. amblycarpa dapat disimpulkan bahwa pemberian ekstrak dosis $100 \mathrm{mg} / \mathrm{kg} \mathrm{BB}, 300 \mathrm{mg} / \mathrm{kg}$ BB dan $600 \mathrm{mg} / \mathrm{kg}$ BB memberikan aktivitas analgesik terhadap mencit dibandingkan dengan kontrol negatif (CMC-Na 1\%).
\end{abstract}

Kata kunci : C. amblycarpa, Kulit Buah, Analgesik, Hot Plate

\begin{abstract}
Nonsteroidal anti-inflammatory drugs (NSAIDs) are the treatment options for relieving pain. However, long-term use can trigger gastrointestinal bleeding. Therefore, alternative analgesics which have the same therapeutic effect with lower side effects are needed. Limau (Citrus amblycarpa) is an empirical drug for tingling and cramping. The aim of the study is to determine the analgesic activity of ethanol extract of C. amblycarpa fruit peel. The method used in testing analgesic activity is the Hot Plate method. The study was conducted by dividing 30 mice into 6 groups. The group given $\mathrm{CMC}-\mathrm{Na} 1 \%$ was used as a negative control, the group given suspension of sodium diclofenac dose of $6.5 \mathrm{mg} / \mathrm{kg}$ of body weight was used as a positive control, and the group given suspension of ethanol extract of C. amblycarpa fruit peel with dose variations 100,300 and $600 \mathrm{mg} / \mathrm{kg}$ of body weight. The test animals were placed on top of the Hot Plate with a temperature of $70^{\circ} \mathrm{C}$ at 30 minutes after giving suspension test and the response time of mice to heat was observed every 30 minutes for 3 hours with cut off time 15 second. Based on the test results, it can be concluded that the administration of ethanol extract of $C$. amblycarpa fruit peel with 100,300 and $600 \mathrm{mg} / \mathrm{kg}$ of body weight gave analgesic activity on mice compared to the negative controls (CMC-Na 1\%).
\end{abstract}

Keywords: C. amblycarpa, Fruit Peel, Analgesics, Hot Plate

\section{PENDAHULUAN}

Nyeri merupakan pengalaman sensorik dan emosional yang tidak menyenangkan akibat kerusakan jaringan atau cenderung merusak jaringan yang ditandai dengan sensasi yang tidak nyaman. Rasa nyeri yang timbul dapat mengakibatkan penurunan aktivitas bahkan kualitas hidup dari pasien. Oleh karena itu, seiring perkembangan dunia kesehatan dilakukan upaya menghilangkan rasa nyeri yang bertujuan untuk mengebalikan kondisi pasien seperti semula serta meningkatkan kualitas hidup pasien. Berdasarkan durasi 
terjadinya nyeri dibedakan menjadi dua kategori yaitu nyeri akut yang terjadi kurang dari tiga bulan dan nyeri kronik yang terjadi lebih dari tiga bulan. Berdasarkan patologi, nyeri dibedakan menjadi dua yaitu nyeri nosiseptif dan nyeri neuropati. Secara umum, nyeri tidak dapat diukur secara kuantitas.

Terapi yang digunakan untuk mengurangi nyeri adalah analgesik baik itu analgesik narkotik maupun non-narkotik. Namun, obat- obatan tersebut dapat menimbulkan efek samping yang perlu diwaspadai jika penggunaan secara berkepanjangan. Hal inilah yang menjadi dorongan bagi peneliti untuk mengembangkan analgesik alternatif dan memiliki efektivitas yang lebih baik serta efek samping yang rendah dibandingkan analgesik sintesis. Salah satu tanaman yang dapat diteliti sebagai analgesik yaitu tanaman jeruk limau $(C$. amblycarpa).

Masyarakat Indonesia khususnya di Bali telah mengenal tanaman- tanaman yang dapat digunakan sebagai obat tradisional yang khasiatnya secara empiris diwariskan. Salah satunya adalah tanaman jeruk limau $(C$. amblycarpa), yang dalam Lontar Usada Taru Premana digunakan untuk pengobatan biulan (kesemutan) dan kram (Putra, 1999). Secara farmakologi kesemutan dan kram merupakan manifestasi dari nyeri neuropati. Pemilihan tanaman ini dikarenakan jeruk limau $(C$. amblycarpa) merupakan salah satu tanaman endemik Indonesia yang memiliki potensi besar sebagai obat, tanaman ini mudah ditemukan karena seing digunakan dalah kehidupan sehari- hari sebagai penambah bumbu masakan. Salah satu senyawa kimia yang telah diketahui memiliki efek analgesik adalah senyawa flavonoid (Janibah, 2009).

Pengujian aktivitas analgesik pada $(C$. amblycarpa) menggunakan metode Hot Plate yang berdasarkan pada rangsangan suhu. Pengujian dilakukan secara in- vivo menggunakan hewan uji mencit jantan. Pada metode ini, hewan uji dibagi menjadi beberapa kelompok dan hewan uji ditempatkan pada lempeng Hot Plate dengan suhu $70^{\circ} \mathrm{C}$ pada 30 menit setelah pemberian suspensi uji dan diamati waktu respon mencit terhadap panas setiap 30 menit selama 3 jam. Dilakukan pengukuran waktu pada hewan uji untuk memberikan respon berupa menjilat telapak kaki, gemetar atau melompat- lompat. Data yang diperoleh kemudian dianalisis dengan software SPSS untuk mengetahui aktivitas analgesik pada ekstrak etanol kulit buah $C$. amblycarpa yang diuji secara in-vivo pada mencit jantan dengan metode hot plate.

\section{BAHAN DAN METODE}

\section{Bahan}

Bahan yang digunakan yakni kulit buah jeruk limau (C. amblycarpa) yang diperoleh di daerah Selumbung, Kec. Manggis, Karangasem, Bali. Kulit buah yang dipilih berasal dari buah yang matang dengan warna hijau tua dan segar (tidak kisut), dipanen dihari yang sama dan diperoleh dari 1 tanaman yang sama atau ditanaman dikebun yang sama. Sedangkan bahan kimia yang digunakan yaitu pelarut etanol $70 \%$, akuades, reagen kimia yang digunakan pada skirining fitokimia serta natrium diklofenak.

\section{Alat}

Alat yang digunakan adalah blender, Hot Plate, Spektrofotometri UV, peralatan gelas, sonde, timbangan analitik, toples kaca, dan seperangkat computer dengan software SPSS dan Microsoft Office.

\section{Metode Penelitian}

Determinasi tumbuhan C. amblycarpa

Determinasi dilakukan di Balai Konservasi Tumbuhan 'Eka Karya' - Lembaga Ilmu Pengetahuan Indonesia (LIPI), Candikuning, Kabupaten Tabanan, Bali.

\section{Pengumpulan sampel kulit buah C.amblycarpa}

Pengumpulan sampel kulit buah $C$. amblycarpa dari daerah Selumbung, Kec. Manggis, Karangasem, Bali yang memenuhi kriteria sampel yang ditetapkan.

\section{Pembuatan serbuk simplisia}

Buah jeruk limau yang telah dicuci bersih dengan air mengalir dikupas dan diambil kulit buahnya, dipotong kecil- kecil lalu dikeringkan dengan cara diangin-anginkan dan terhindar dari sinar matahari langsung (Depkes RI, 1995). Kulit buah yang kering dihaluskan menggunakan blender, kemudian diayak dengan ayakan Mesh 60 hingga diperoleh serbuk halus dan ukuran yang homogen. 


\section{Penetapan kadar air serbuk simplisia}

Penetapan kadar air serbuk simplisia untuk mengetahui persentase kadar air yang terdapat pada serbuk simplisia untuk menghindari pertumbuhan mikroorganisme dan jamur jika kadar air pada serbuk simplisia rendah.

\section{Pembuatan ekstrak etanol kulit buah $C$. amblycarpa}

Serbuk simplisia C. amblycarpa dimaserasi dengan menggunakan pelarut etanol $70 \%$. Pengadukan dilakukan setiap 24 jam. Maserat hasil maserasi disaring dan ampasnya diremaserasi sebanyak dua kali pengulangan. Maserat yang diperoleh kemudian diuapkan dengan vacuum rotary evaporator pada suhu $50^{\circ} \mathrm{C}$ hingga diperoleh ekstrak kental. Rendemen ekstrak dihitung dengan menggunakan persamaan sebagai berikut (Adrianto et al., 2014).

$\%$ rendemen $=\underline{\text { Bobot ekstrak diperoleh } \mathrm{x} 100 \%}$ Bobot serbuk yang digunakan

\section{Skrining fitokimia ekstrak etanol kulit buah C. amblycarpa}

Skrining fitokimia dilakukan untuk mengetahui kandungan senyawa yang terdapat pada ekstrak etanol kulit buah $C$. amblycarpa. Dilakukan pemeriksaan senyawa kimia yakni pemeriksaan alkaloid, saponin, flavonoid, polifenol dan tanin, glikosida, triterpenoid dan steroid, dan minyak atsiri.

\section{Uji aktivitas analgesik ekstrak etanol kulit} buah $C$. amblycarpa

Mencit dibagi menjadi 6 kelompok yakni kelompok I sebagai kontrol normal (tidak mendapatkan perlakuan), kelompok II sebagai kontrol negatif yakni diberikan cairan pembawa (CMC-Na 1\%), kelompok III diberikan suspensi natrium diklofenak dosis $6,5 \mathrm{mg} / \mathrm{kgBB}$ sebagai kontrol positif. Kelompok VI, V, VI diberikan suspensi ekstrak kulit buah $C$. amblycarpa dengan rentang dosis 100, 300, dan $600 \mathrm{mg} / \mathrm{kg}$ BB. Setelah 30 menit diberi perlakuan, hewan uji ditempatkan di atas Hot Plate dengan suhu $70^{\circ} \mathrm{C}$. Waktu yang terlewat antara penempatan hewan di hot plate dan adanya perilaku menjilati telapak kaki atau melompat dari permukaan tercatat sebagai respon latensi dalam hitungan detik. Jumlah respon diukur pada menit ke-30, 60, 90, 120, 180 setelah pemberian suspensi ekstrak. Waktu cut-off untuk latensi plat panas ditetapkan pada 15 detik (Sivananda et al., 2013).

\section{Analisis data}

Analisis data dilakukan secara statistik menggunakan uji Shapiro- Wilk, uji Levene. Jika distribusi data telah normal dan homogen $\mathrm{p}>0,05$ maka dilanjutkan dengan analisis parametrik metode one way ANOVA dengan menggunaka program SPSS dengan tingkat kepercayaan $95 \% \quad(\mathrm{p}>0,05)$. Selanjutnya dilakukan uji Post Hoc dengan uji LSD untuk mengetahui kelompok mana yang memiliki pengaruh sama atau berbeda. Jika data tidak terdistribusi normal dan atau data tidak terdistribusi homogen maka dilakukan uji statistic non-parametrik (uji Kruskall-Wallis) (Wells et al, 2015).

\section{HASIL DAN PEMBAHASAN}

\section{Ekstrak etanol kulit buah C. amblycarpa}

Ekstraksi kulit buah $C$. amblycarpa dilakukan dengan metode maserasi. Maserasi digunakan untuk mengekstraksi sampel yang tidak stabil pada suhu tinggi. Pada proses ekstraksi dilakukan maserasi terhadap $500 \mathrm{mg}$ serbuk simplisia kulit buah $C$. amblycarpa dalam pelarut etanol $70 \%$ sebanyak $5 \mathrm{~L}$ untuk sekali tahap maserasi dan dilakukan remaserasi sebanyak 2 kali. Filtrat hasil maserasi kemudian dipekatkan dengan menggunakan vacuum rotatory evaporator. Ekstrak kental yang diperoleh sebanyak 107,015 gram sehingga persentase rendemen ekstrak yakni $21,403 \%$ (b/b). Berdasarkan hasil skrinning fitokimia diketahui bahwa senyawa yang terkandung dalam ekstrak etanol kulit buah $C$. amblycarpa terdiri dari flavonoid, polifenol, tannin, glikosida, dan minyak atsiri.

\section{Uji aktivitas analgesik ekstrak etanol kulit buah $C$. amblycarpa}

Pengujian aktivitas analgesik dilakukan secara in-vivo menggunakan makhluk hidup utuh sebagai subjek penelitian. Hewan uji yang digunakan sebagai sampel penelitian adalah 30 ekor mencit putih jantan galur balb/c berusia 4 minggu dan telah memenui kriteria inklusi yang ditetapkan. Pemilihan hewan uji 
berdasarkan kesamaan fisiologis dengan manusia serta kemudahan dalam pemeliharaan dan perlakuan (Arrington, 1972).

Uji aktivitas analgesik ekstrak etanol kulit buah $C$. amblycarpa dilakukan dengan metode hot plate, dilakukan pengamatan waktu respon hewan uji terhadap stimulus panas dari hot plate setelah 30 menit setelah pemberian suspensi CMC-Na $1 \%$ pada kelompok kontrol negatif, suspensi natrium diklofenak pada kelompok kontrol positif dan suspensi ekstrak etanol kulit buah $C$. amblycarpa dengan variasi dosis $100 \mathrm{mg} / \mathrm{kg} \mathrm{BB}, 300 \mathrm{mg} / \mathrm{kg} \mathrm{BB}$, dan 600 $\mathrm{mg} / \mathrm{kg} \mathrm{BB}$ pada kelompok perlakuan. Metode hot plate banyak digunakan untuk menguji analgesik untuk nyeri nosiseptif melalui stimulasi suhu dari hot plate yang memberikan rasa nyeri pada hewan uji. Efektivitas analgesik dapat diketahui dengan membandingkan waktu respon hewan uji terhadap stimulasi panas antara kelompok kontrol negatif, kontrol positif, dan kelompok yang diberikan ekstrak dengan variasi dosis (Patel et al., 2016).

Pengamatan respon hewan uji terhadap stimulasi panas dilakukan setiap 30 menit selama 3 jam dimana pengamatan selama 3 jam ini didasarkan pada waktu paruh Natrium Diklofenak yaitu 1-3 jam (Altaher et al., 2006). Waktu respon hewan uji terhadap stimulasi panas pada masing-masing kelompok selanjutnya akan digunakan untuk mencari aktivitas analgesik. Rata-rata persentase aktivitas analgesik pada masing-masing kelompok dapat dilihat pada Tabel 1 dan grafik pada Gambar 1 di bawah ini.

Tabel 1. Tabel Rata-Rata Persentase Aktivitas Analgesik tiap Waktu Pengamatan

\begin{tabular}{|l|l|l|l|l|l|l|}
\hline \multirow{2}{*}{ Kelompok uji } & \multicolumn{7}{|c|}{ Rata-rata aktivitas analgesik (detik) } \\
\cline { 2 - 7 } & 30 menit & 60 menit & 90 menit & 120 menit & 150 menit & 180 menit \\
\hline Kelompok I & 1.8 & 1.6 & 2 & 1.8 & 2.2 & 2.6 \\
\hline Kelompok II & 2.4 & 2 & 2 & 2.2 & 2.2 & 2.6 \\
\hline Kelompok III & 10.8 & 11.8 & 13.4 & 11.8 & 12.6 & 11 \\
\hline Kelompok IV & 3.6 & 3.6 & 5.2 & 5.6 & 4.4 & 4.4 \\
\hline Kelompok V & 6.4 & 7.8 & 9 & 9.2 & 7.2 & 6.2 \\
\hline Kelompok VI & 9.2 & 10.8 & 12.6 & 12.6 & 10 & 12.4 \\
\hline \multirow{2}{*}{ Kelompok uji } & 30 menit & 60 menit & 90 menit & 120 menit & 150 menit & 180 menit \\
\cline { 2 - 8 } & 4.54 & 2.98 & 0 & 3.03 & 0 & 0 \\
\hline Kelompok II & 75.38 & 87.69 & 75 & 81.25 & 67.74 \\
\hline Kelompok III & 66.67 & 12.31 & 24.61 & 26.56 & 17.18 & 14.51 \\
\hline Kelompok IV & 9.52 & 44.61 & 53.85 & 54.68 & 39.06 & 29.03 \\
\hline Kelompok V & 31.74 & 67.70 & 81.54 & 81.25 & 84.38 & 79.03 \\
\hline Kelompok VI & 44.62 & \multicolumn{7}{|c|}{ Rata-rata persentase aktivitas analgesik (\%) } \\
\hline
\end{tabular}

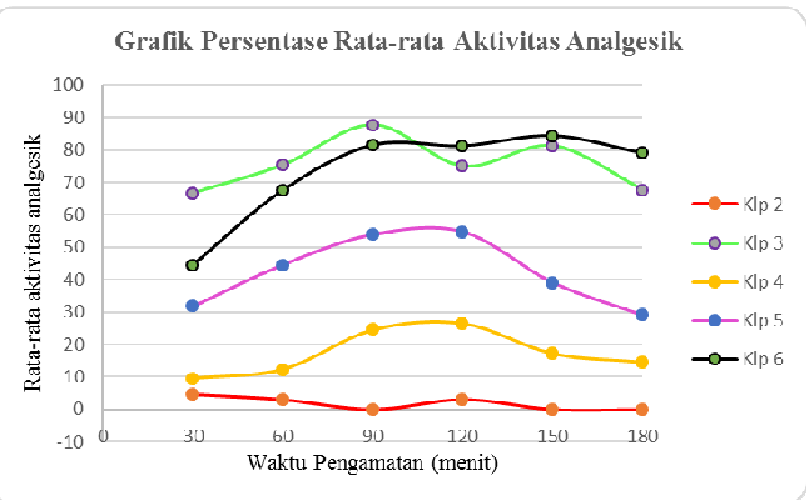

Gambar 1. Grafik Rata-Rata Persentase Aktivitas Analgesik tiap Waktu Pengamatan
Terdapat perbedaan antara nilai ratarata aktivitas analgesik ketiga kelompok uji dan kelompok kontrol negatif dimana perbedaan ini membuktikan bahwa terdapat aktivitas analgesik dari ekstrak etanol kulit buah $C$. amblycarpa. Diantara ketiga kelompok uji, kelompok uji dosis $100 \mathrm{mg} / \mathrm{kg}$ BB memiliki nilai rata-rata aktivitas analgesik yang paling rendah dibandingkan dengan kelompok uji dosis $300 \mathrm{mg} / \mathrm{kg}$ BB dan 600 $\mathrm{mg} / \mathrm{kg} \mathrm{BB}$. Sedangkan kelompok uji dosis 600 $\mathrm{mg} / \mathrm{kgBB}$ memiliki nilai rata-rata aktivitas paling tinggi dibandingkan dengan kelompok uji dosis $300 \mathrm{mg} / \mathrm{kg}$ BB dan $100 \mathrm{mg} / \mathrm{kg} \mathrm{BB}$. 
Data hasil uji analgesik masing-masing hewan uji dianalisis secara statistik dengan menggunakan SPSS. Normalitas data diuji dengan Uji Shapiro-Wilk dan uji Levene untuk mengetahui homogenitas sebaran data. Hasil uji Shapiro-Wilk dapat disimpulkan bahwa data tidak terdistribusi normal, serta hasil uji Levene dapat disimpulkan bahwa sebaran data tidak homogen. Oleh karena syarat analisis parametrik tidak terpenuhi (data tidak normal dan tidak homogen), maka uji One Way ANOVA tidak dapat dilakukan. Data dianalisis menggunakan analisis non-parametrik, yakni menggunakan uji Kruskall-Wallis untuk mengetahui adanya perbedaan bermakna, dan dilanjutkan dengan uji Mann-Whitney U untuk melihat perbedaan antara tiap kelompok perlakuan (Besral, 2010).

Hasil uji Kruskall-Wallis menunjukkan terdapat perbedaan bermakna $(\mathrm{p}<0,05)$ pada seluruh waktu pengamatan sehingga menunjukkan adanya perbedaan bermakna antara kelompok perlakuan. Hasil uji Mann-Whitney $U$ antara kelompok kontrol normal dan kelompok kontrol negatif menunjukkan tidak adanya perbedaan berrmakna $(p>0,05) \quad$ sehingga dapat disimpulkan bahwa tidak adanya aktivitas analgesik pada kelompok kontrol negatif yang diberi perlakuan pemberian CMC-Na $1 \%$ secara peroral. Hal ini membuktikan bahwa suspensi CMC-Na tidak memberikan aktivitas sebagai analgesik.

Hasil uji Mann-Whitney $U$ antara kelompok kontrol negatif dan kelompok uji dengan pemberian suspensi ekstrak etanol kulit buah $C$. amblycarpa variasi dosis $100 \mathrm{mg} / \mathrm{kg}$ $\mathrm{BB}, 300 \mathrm{mg} / \mathrm{kg} \mathrm{BB}$, dan $600 \mathrm{mg} / \mathrm{kg} \mathrm{BB}$ menunjukkan adanya perbedaan bermakna $(\mathrm{p}<0,05)$ sehingga dapat disimpulkan bahwa ekstrak etanol kulit buah $C$. amblycarpa memiliki aktivitas analgesik. Hasil MannWhitney $U$ antara kelompok uji dengan pemberian ekstrak dosis $600 \mathrm{mg} / \mathrm{kg}$ BB dan kontrol positif menunjukkan tidak adanya perbedaan bermakna $(p>0,05)$ sehingga dapat disimpulkan bahwa aktivitas analgesik ekstrak etanol kulit buah C. amblycarpa $600 \mathrm{mg} / \mathrm{kg}$ BB hampir mirip dengan aktivitas analgesik suspensi natrium diklofenak dosis $6,5 \mathrm{mg} / \mathrm{kg}$ BB. Hasil uji Mann-Whitney U antara ketiga kelompok yang diberikan suspensi ekstrak variasi dosis $100 \mathrm{mg} / \mathrm{kg} \mathrm{BB}, 300 \mathrm{mg} / \mathrm{kgBB}$, dan
$600 \mathrm{mg} / \mathrm{kgBB}$ menunjukkan adanya perbedaan bermakna $(\mathrm{p}<0,05)$ sehingga dapat dikatakan bahwa aktivitas yang diberikan oleh ekstrak berbeda sesuai dengan perbedaan dosis yang diberikan kepada hewan uji.

\section{SIMPULAN DAN SARAN}

\section{Simpulan}

Ekstrak etanol kulit buah jeruk limau (C. amblycarpa) memiliki aktivitas analgesik pada mencit jantan galur Balb/c terhadap stimulasi nyeri melalui metode hot plate. Aktivitas analgesik yang diberikan oleh ekstrak berbeda sesuai dengan perbedaan dosis yang diberikan kepada hewan uji. Dosis $600 \mathrm{mg} / \mathrm{kg}$ BB memiliki nilai rata-rata aktivitas analgesik paling tinggi dibandingkan dengan dosis $300 \mathrm{mg} / \mathrm{kg} \mathrm{BB}$ dan $100 \mathrm{mg} / \mathrm{kg} \mathrm{BB}$.

\section{Saran}

Data menunjukkan semakin tinggi dosis ekstrak yang diberikan pada hewan uji, semakin besar aktifitas analgesiknya, sehingga perlu dilakukan penelitian lebih lanjut dengan dosis lebih tinggi sampai maksimumnya.

\section{UCAPAN TERIMA KASIH}

Penulis mengucapkan terima kasih kepada dosen pembiming, keluarga, temanteman, dan semua pihak yang telah membantu dan mendukung dalam penelitian ini.

\section{DAFTAR PUSTAKA}

Adrianto, H., S. Yotopranoto, Hamidah. 2014. Efektivitas Ekstrak Daun Jeruk Purut (Citus hystrix), Jeruk Limau (Citrus amblycarpa), dan Jeruk Bali (Citrus maxima) terhadap Larva Aedes aegypti. Aspirator. Vol. 6(1): 1-6.

Altaher, A. Y., K. M. Alkharfy, B. M AlHadiya, dan R. M. A. Khan. 2006. Pharmacokinetics of Diclofenac In Sheep Following Intravenous And Intramuscular Administration. Veterinary Anaesthesia and Analgesia. Vol. 33: 241-245.

Arrington, L. R. 1972. Introductory Laboratory Animal Science. Danville, 
Illinois: The Interstate Printer and Publisher.

Besral. 2010. Pengolahan dan Analisa Data-1 Menggunakan Program SPSS. Jakarta: Departemen Biostatistika Fakultas Kesehatan Masyarakat Universitas Indonesia.

Depkes RI. 1995. Farmakope Indonesia, Edisi Keempat. Jakarta: Departemen Kesehatan Republik Indonesia.

Janibah, R. 2009. Uji Sitotoksik Ekstrak Etanol Herba Bandotan (Ageratum conyzoides L.) terhadap Sel T47D dan Profil Kromatografi Lapis Tipis. Fakultas Farmasi, Universitas Muhammadiyah Surakarta, Surakarta.

Patel, P. K. Sahu, dan S.S. Chandel. 2016. A Detailed Review on Nociceptive Models for the Screening of Analgesic Activity in Experimental Animals. International Journal of Neurologic Physical Therapy. 2(6): 44-50.
Putra, I.G.S. 1999. Taru Pramana Khasiat Tanam-tanaman untuk Obat Tradisional. Denpasar: PT. Upada Sastra.

Shivananda, A., D. R. Muralidhara, and K.N. Jayaveera. 2013. Analgesic and AntiInflammatory Activities of Citrus Maxima (J. Burm) Merr in Animal Models. Research Journal of Pharmaceutical, Biological and Chemical Sciences. 4(2): 1800-1810.

Wells, B.G., Dipiro, J.T., Schwinghammer, T.L., Dipiro, C.V. 2015. Pharmacotherapy Handbook. Ninth Edition. McGraw-Hill Companies. 